\title{
Analysis of Indicators of Sustainable Development Goals for Rural Areas of Russia
}

\author{
Lyudmila G. Glubokova ${ }^{1,{ }^{*}}$ Dmitry V. Kokhanenko ${ }^{2}$ Sergey Y. Shevelev ${ }^{2}$ \\ Marina A. Ilyina ${ }^{2}$ \\ ${ }^{I}$ International Institute of Economics, Management and Informational Systems(IIEMIS), Altai State University, Barnaul \\ 656049, Russia \\ ${ }^{2}$ Financial University under the Government of the Russian Federation, Moscow 125167, Russia \\ ${ }^{*}$ Corresponding author. E-mail: glg72@mail.ru
}

\begin{abstract}
Sustainable rural development is a global problem. The importance of this issue lies in the fact that economically sustainable and socially developed rural territories guarantee stability, independence and food security of the state, therefore the direction of their development becomes a national policy priority. The solution to this scientific problem is the emergence of a new area in scientific research of sustainable rural development by substantiating the necessary conceptual framework and determining the indicators of rural development in accordance with the goals of sustainable development.

Keywords: sustainable development of rural areas, sustainable development goals, non-economic factors,
\end{abstract}

indicators of sustainable development of rural areas

\section{INTRODUCTION}

Sustainable development issues were first presented at a United Nations session through the «Brundtland commission» (World Commission on Environment and Development) in 1987. Subsequently, the issues of sustainable development were repeatedly reviewed, for instance, such issues as rational use of natural resources and improving the well-being of living people without harming future generations were voiced at the UN Conference on Environment and Development (UNCED) in Rio de Janeiro in 1992, where the necessity for the entire world community to move to the path of sustainable development was proclaimed [1]. It is obvious that the world's regenerative potential is overburdened, and natural capital becomes a limiting factor for current and future human activities. In 2012, the UN Conference decided to create a Working Party and in 2015 this team presented recommendations with the view of determining 17 Sustainable Development Goals and reflected them in the final document «Transforming our world: the 2030 Agenda for Sustainable Development».

The term «sustainable development» was first used in the report «Our common future» at a session of the UN World Commission on Environment and Development headed by Gro Harlem Brundtland. According to the report, sustainable development is «not a fixed state of harmony, but rather a process of change in which the exploitation of resources, the direction of investments, the orientation of technological development, and institutional change are made consistent with future as well as present needs» [2]. At the same time the concept of «sustainable development» emerged as an economic category, but scientists and researchers did not agree on this term. However, most of them understand the basic principle of sustainable development as the movement of society to the future on the basis of reasonable compromises in the interactions between society and nature, as well as among individuals. A more specific definition of the term «sustainable development» is given by O. Dreyer and V. Los, who note that «this is economic growth ensuring meeting the material and spiritual needs of both present and future generations, while maintaining a balance of historically formed ecosystems; a base of a «sustainable civilization» [3]. The Word Bank experts suggested a practical meaning of the sustainable development as «managing the total capital of society in the interests of preserving and enriching human capabilities» [4]. The main controversy in the global economic science regarding the concept of «sustainable development» is mainly dedicated to the search of means to attain the objective (to ensure sustainable development of society while preserving existing resources). The scientific research into sustainable development is mainly based on scientific papers of some scientists, both Russian (Agafonov N. T., Belov A. A., Gorshkov V. G., Golubev V. S., DanilovDanilyan V. I., Islyaev R. A., Kondratiev K. Ya., Kostyaev A. I., Lukyanchikov N. N., Makarov S. V., Merzlov A.V., Myagkov S. M., Tarasov V. V., Sokolov O. A., Ursul A.D., Chernikov V. A., Shanovalova N. P., etc.) and foreign (Bryson T., Meadows D. H., Meadows D. L., North K., Randers I.). 


\section{GOALS AND OBJECTIVES}

The goal of the work is to determine indicators of sustainable development of rural areas in accordance with the requirements of the Sustainable Development Goals. The implementation of this goal involves achieving the following objectives:

- to define the objectives of sustainable development of rural territories;

- analyze the formation of indicators for sustainable rural development goals;

- analyze the contribution of agricultural production to the gross regional product.

\section{BACKGROUND}

Russia is working hard to implement the Sustainable Development Goals adopted by the UN General Assembly in 2015. In particular, the country cooperates with international organizations of the UN system, works on projects to ensure food security, modernize infrastructure and solve the economic problems of developing countries [5].

The most important country's resource in the framework of sustainable development is the rural territories of the Russian Federation, which importance is rapidly growing in the context of deepening globalization and increasing role of the natural and territorial resources. However, the current social and economic situation in Russian rural areas is characterized by accumulated problems that hinder its transition to sustainable development. The crisis in rural areas caused by the beginning of the current reforms has not been overcome yet. The pre-reform level of production in the agricultural sector has not been reached yet, there is still a downward tendency in the resource potential of agriculture, and the process of forming economically active rural business entities has not been completed. The demographic and environmental situation is deteriorating, and the social infrastructure is being destroyed. Lowquality living environment, limited work opportunities and lower (compared to urban) income levels in rural areas have significantly affected the labour outflow processes in rural areas which in turn caused the growth of social and economic imbalance as well as the emergence of depressed rural areas, where many economic, social and environmental problems are exacerbating, leading to overall volatility and disintegration of the Russian economy [6]. Meanwhile, every region follows its own approaches to rural development often not taking into account the current social and economic situation at the district level and features of rural settlements, which slows down the development process, reduces the effectiveness of territory management at all levels. Despite the dynamic growth of agro-based industries, the living standards and life quality of the rural population are significantly behind the living standards in cities, the access of the population to the services of social organizations is narrowing, the information and innovation gap between urban and rural areas is deepening, which results in the increasing migration outflow of the rural population, in the loss of land development. Today the development of rural areas is extremely uneven [7]. The assessment of social and economic development of Russian regions for 2018, shown in Table 1, confirms this assertion. Based on Rosstat data on gross regional product and agricultural output, you can rate regions on agricultural output in all kinds of farms (Table 1) [8]. It should be noted that the first 20 regions of Russia produce $66,6 \%$ of agricultural output, which is $4,1 \%$ of of the total gross regional product.If we compare this indicator for all regions, it makes $6,9 \%$. Table 2 shows the rating of regions on the agricultural output share in the gross regional product [8]. The calculations confirm that the agricultural output accounts a large part of the gross regional product that is why any decisions in the field of social and economic development of rural areas will be relevant both for agriculture and for the region. A comprehensive economic literature review confirms that these indicators are used to form various ratings to assess sustainable development of regions $[7,9,10]$.

Table 1 the Top twenty regions of the Russian Federation, leading in agricultural output in 2018.

\begin{tabular}{|l|c|c|}
\hline \multicolumn{1}{|c|}{ Region } & $\begin{array}{c}\text { Agricultural } \\
\text { products - total, } \\
\text { million rubles }\end{array}$ & Rank \\
\hline Krasnodar territory & 382468 & 1 \\
\hline Belgorod region & 257038 & 2 \\
\hline Rostov region & 255129 & 3 \\
\hline $\begin{array}{l}\text { Republic of } \\
\text { Tatarstan }\end{array}$ & 226034 & 4 \\
\hline Voronezh region & 219151 & 5 \\
\hline Stavropol territory & 195858 & 6 \\
\hline $\begin{array}{l}\text { Republic of } \\
\text { Bashkortostan }\end{array}$ & 157486 & 7 \\
\hline Kursk region & 146703 & 8 \\
\hline Altai territory & 131825 & 9 \\
\hline Saratov region & 129175 & 10 \\
\hline Volgograd region & 128275 & 11 \\
\hline Tambov region & 127308 & 12 \\
\hline $\begin{array}{l}\text { Republic of } \\
\text { Dagestan }\end{array}$ & 124371 & 13 \\
\hline Chelyabinsk region & 119417 & 14 \\
\hline Lipetzk region & 119304 & 15 \\
\hline Moscow region & 108423 & 16 \\
\hline Orenburg region & 107971 & 17 \\
\hline Omsk region & 94097 & 18 \\
\hline Leningrad region & 91717 & 19 \\
\hline Samara region & 88976 & 20 \\
\hline
\end{tabular}


Table 2 Rating of regions of the Russian Federation, leading in the agricultural output share in the gross regional product in 2018

\begin{tabular}{|c|c|c|}
\hline Region & $\begin{array}{l}\text { Agricultural } \\
\text { output share in } \\
\text { the gross } \\
\text { regional } \\
\text { product, \% }\end{array}$ & Rank \\
\hline Tambov region & 42 & 1 \\
\hline $\begin{array}{l}\text { Republic of } \\
\text { Kalmykia }\end{array}$ & 40 & 2 \\
\hline $\begin{array}{l}\text { Karachaevo- } \\
\text { Chercessian } \\
\text { Republic }\end{array}$ & 40 & 3 \\
\hline Kursk region & 38 & 4 \\
\hline $\begin{array}{l}\text { Kabardino- } \\
\text { Balkarian Republic }\end{array}$ & 36 & 5 \\
\hline Oryol region & 34 & 6 \\
\hline Belgorod region & 33 & 7 \\
\hline $\begin{array}{l}\text { Republic of } \\
\text { Mordovia }\end{array}$ & 30 & 8 \\
\hline Stavropol territory & 29 & 9 \\
\hline Bryansk Region & 28 & 10 \\
\hline Republic of Altai & 26 & 11 \\
\hline Altai territory & 26 & 12 \\
\hline Republic of MarijEl & 26 & 13 \\
\hline Voronezh region & 25 & 14 \\
\hline Pskov region & 24 & 15 \\
\hline Lipetzk region & 24 & 16 \\
\hline Penza region & 23 & 17 \\
\hline $\begin{array}{l}\text { Republic of } \\
\text { Adygeya }\end{array}$ & 22 & 18 \\
\hline $\begin{array}{l}\text { Republic of } \\
\text { Dagestan }\end{array}$ & 20 & 19 \\
\hline Saratov region & 19 & 20 \\
\hline
\end{tabular}

According to the research on the issues of sustainable development of rural areas in Russia in the scientific environment there are two following areas:

- sustainable development with a strong environmental focus;

- rural development associated with the social orientation and complexity of rural development.

The first area is represented mainly by ecologists, who focus their research on resource constraints associated not only with the limitations of mineral resources, but also with the interaction between the anthroposystem and the biosphere and their mutual influence. According to these scientists, "sustainable development is a development in which environmental impacts remain within the economic capacity of the biosphere, therefore the natural basis for human life reproduction is not destroyed» [11].

Within the second area, the social development of the village is considered as an important element of its sustainable development, on the one hand, and on the other hand - as a significant factor determining the sustainable development of rural areas. The importance of the issues raised is expounded in tarticles of Tretyakova L. A. [12], Merenkova I. N., Pertseva V. N. [13], Dronova M. V. [14], etc. All the opinions of scientists on the concept of «sustainable development of rural areas» more or less affect the concepts of «sustainable development», «regularity and continuity of changes», «efficiency gains», «maintaining of growth», etc. The scientific research of Merzlov A.V. [15], Ovchintseva L. A. and Nikonov A. A. and some other scientists allow to elaborate on "The Strategy of Sustainable Development of Rural areas of the Russian Federation for the Period till 2030».At present according to the Strategy, rural territories, beinga social and territorial subsystem of society, perform the following important national functions: production; demographic; labor resources; housing; spatial communication; social control over a rural territory.

Despite the considerable elaboration of the issues indicated above, some of them have not been sufficiently studied, which means that many theoretical and methodological problems of sustainable rural development require further consideration.Unexplored aspects are stipulated by the methodology of research on sustainable rural development, insufficient knowledge of factors, features, models and mechanisms, as well as the characteristics and conditions of rural development.So far experts haven't agreed on the meaning of sustainable rural development, and the existing views on this category do not fully meet its interpretation by international institutions.Criteria and indicators that correspond to the sustainable rural development goals have not yet been identified to determine the level and intensity of fluctuation in sustainable development.An assessment technique taking into account integrated influence of all rural development factors has not been developed.

Existing methods of assessment of rural development sustainability are focused on macro -, at best, meso-levels, and are not applied at the level of rural settlements, which does not allow identifying the socio-economic potential necessary to support the process of adaptation of rural areas to the changes that meet the principles and concepts of the sustainable development paradigm.

To guarantee the socio-economic potential and stable improvement of living standards for the rural population in Russia the Russian state adopted a number of documents: «Strategy of sustainable rural development in the Russian Federation for the period up to 2030», Conception of sustainable rural development in the Russian Federation for the period up to 2020, approved by decree of the Russian Federation government from November 30, 2010 N 2136-p, a state program of the Russian Federation «Complex development of rural territories», approved by Russian Federation Government Resolution from may 31, 2019 No. 696.

The sustainable development of rural areas is determined by the rural development indicators gained as a result of the implementation of program activities, which by their characteristics are poorly related to the sustainable development goals. The uniqueness of these goals is that they call on all countries - developed and developing - to promote welfare while protecting the planet. They recognize that poverty eradication must be inextricably 
linked with the implementation of strategies that promote economic growth and are aimed at a range of social needs, including education, health, social welfare and employment opportunities, while protecting the environment and solving problems caused by climate change.

Currently, Rosstat is conducting a number of activities to collect and present official statistical information on sustainable development goals indicators in the Russian Federation in accordance with international standards. The territorial department of Rosstat in Rostov region in cooperation with Ministries and Agencies has developed a draft list of national sustainable development goals indicators. To implement 167 objectives of all sustainable development goals 364 indicators, including 70 (19\%) indicators with the level of aggregation of official statistical information on constituent entities of the Russian Federation have been formulated [16]. Table 3 provides the information on the number of developed indicators used to assess the sustainable development of regions, which are to include the target indicators of the state program of the Russian Federation «Integrated development of rural areas».

Table 3 National SDG indicators proposed for assessing sustainable rural development

\begin{tabular}{|c|c|c|c|}
\hline \multirow[b]{2}{*}{$\begin{array}{l}\text { Name of Sustainable } \\
\text { Development Goals }\end{array}$} & \multirow{2}{*}{$\begin{array}{l}\text { Number } \\
\text { of } \\
\text { indicators } \\
\text { registered } \\
\text { by } \\
\text { Rosstat } \\
\end{array}$} & \multicolumn{2}{|c|}{$\begin{array}{l}\text { State program of the Russian Federation «Integrated development of rural territories» dated May 31, } \\
2019 \text { No. } 696\end{array}$} \\
\hline & & $\begin{array}{l}\text { Number of } \\
\text { indicators }\end{array}$ & Names of indicators and their serial numbers \\
\hline $\begin{array}{l}\text { Goal1. Reduce global } \\
\text { poverty in all its } \\
\text { forms }\end{array}$ & 32 & & \\
\hline $\begin{array}{l}\text { Goal } 2 \text {. End hunger, } \\
\text { achieve food security } \\
\text { and improve nutrition } \\
\text { and promote } \\
\text { sustainable } \\
\text { agriculture. }\end{array}$ & 21 & 5 & $\begin{array}{l}\text { 2.The area of reclaimed land put into operation due to reconstruction, technical re-equipment } \\
\text { and construction of new reclamation systems for General and individual use. } \\
\text { 4. Involvement in the turnover of retired agricultural land through cultural and technical } \\
\text { measures. } \\
\text { 6. Prevention of the retirement of reclaimed land from agricultural turnover due to the } \\
\text { reconstruction, technical re-equipment and construction of objects of the reclamation complex of } \\
\text { state property of the Russian Federation (increasing total by 2018). } \\
\text { 7. Protection of land from water erosion, flooding due to reconstruction, technical re-equipment } \\
\text { and construction of land reclamation facilities of the state property of the Russian Federation } \\
\text { (cumulative total by 2018). } \\
\text { 30. Number of local initiatives implemented by citizens living in rural areas who received grant } \\
\text { support. }\end{array}$ \\
\hline $\begin{array}{l}\text { Goal 3.Ensure } \\
\text { healthy lives and } \\
\text { promote well-being } \\
\text { for all at all ages. }\end{array}$ & 47 & 6 & $\begin{array}{l}\text { 18. Commissioning of paramedic and midwifery centers and (or) offices of General } \\
\text { practitioners. } \\
\text { 19. Increase in the rural population provided by paramedic and midwifery centers (offices of } \\
\text { General practitioners) (cumulative total). } \\
\text { 20. Commissioning of flat sports facilities. } \\
\text { 21. Increase in the rural population provided with flat sports facilities (cumulative total). } \\
\text { 22. Commissioning of cultural and leisure institutions. } \\
\text { 23. Increase in the rural population provided by cultural and leisure institutions (cumulative). }\end{array}$ \\
\hline $\begin{array}{l}\text { Goal 4. Ensure } \\
\text { inclusive and quality } \\
\text { education for all and } \\
\text { promote lifelong } \\
\text { learning. }\end{array}$ & 43 & 3 & $\begin{array}{l}\text { 16. Commissioning of General education organizations. } \\
\text { 17. Reduction in the number of students in General education organizations that are in an } \\
\text { emergency state in rural areas (increasing total). } \\
\text { 31. Number of implemented measures to promote and popularize achievements in the field of } \\
\text { rural development. }\end{array}$ \\
\hline $\begin{array}{l}\text { Goal 5. Ensure } \\
\text { gender equality and } \\
\text { empower all women } \\
\text { and girls. }\end{array}$ & 5 & & \\
\hline $\begin{array}{l}\text { Goal 6. Ensure } \\
\text { access to water and } \\
\text { sanitation for all. }\end{array}$ & 12 & 7 & $\begin{array}{l}\text { 9. Bringing state hydraulic structures into safe operating condition. } \\
\text { 11. Reduction of the share of state property of the Russian Federation in the total volume of } \\
\text { reclamation systems and separately located hydraulic structures (decreasing total). } \\
\text { 12. Commissioning of state-owned land reclamation facilities in the Russian Federation. } \\
\text { 24. Commissioning of gas distribution networks. } \\
\text { 25. The level of gasification of residential buildings (apartments) with network gas in rural } \\
\text { areas. } \\
\text { 26. The commissioning of the local water supply. } \\
\text { 27. The level of provision of rural population with drinking water. }\end{array}$ \\
\hline $\begin{array}{l}\text { Goal 7. Ensure } \\
\text { access to affordable, } \\
\text { reliable, sustainable } \\
\text { and modern energy } \\
\text { sources for all. }\end{array}$ & 5 & & \\
\hline
\end{tabular}




\begin{tabular}{|c|c|c|c|}
\hline \multirow{2}{*}{$\begin{array}{l}\text { Name of Sustainable } \\
\text { Development Goals }\end{array}$} & \multirow{2}{*}{$\begin{array}{l}\text { Number } \\
\text { of } \\
\text { indicators } \\
\text { registered } \\
\text { by } \\
\text { Rosstat } \\
\end{array}$} & \multicolumn{2}{|c|}{$\begin{array}{l}\text { State program of the Russian Federation «Integrated development of rural territories» dated May 31, } \\
2019 \text { No. } 696\end{array}$} \\
\hline & & $\begin{array}{l}\text { Number of } \\
\text { indicators }\end{array}$ & Names of indicators and their serial numbers \\
\hline $\begin{array}{l}\text { Goal 8. Promote } \\
\text { sustained, inclusive } \\
\text { and sustainable } \\
\text { economic growth, full } \\
\text { and productive } \\
\text { employment and } \\
\text { decent work for all. }\end{array}$ & 34 & 2 & $\begin{array}{l}\text { 1. Increase in crop production on agricultural land (on a cumulative total). } \\
\text { 32. Number of jobs created in rural areas. }\end{array}$ \\
\hline $\begin{array}{l}\text { Goal 9. Create a } \\
\text { robust infrastructure, } \\
\text { promote inclusive } \\
\text { and sustainable } \\
\text { industrialization and } \\
\text { foster innovation. }\end{array}$ & 21 & 2 & $\begin{array}{l}\text { 28. Commissioning of paved public roads leading from the network of public roads to the } \\
\text { nearest socially significant objects of rural localities, as well as to objects of production and } \\
\text { processing of agricultural products. } \\
\text { 29. The number of localities located in rural areas where projects have been implemented for the } \\
\text { integrated development of sites for housing development. }\end{array}$ \\
\hline $\begin{array}{l}\text { Goal 10. Reduce } \\
\text { inequality within and } \\
\text { between countries. }\end{array}$ & 14 & & \\
\hline $\begin{array}{l}\text { Goal 11. Ensure the } \\
\text { openness, security, } \\
\text { resilience and } \\
\text { sustainability of cities } \\
\text { and localities. }\end{array}$ & 49 & 3 & $\begin{array}{l}\text { 13. Introduction (purchase) of housing for citizens living in rural areas (annually). } \\
\text { 14. Reduction of the total number of families in need of improved housing conditions in rural } \\
\text { areas (cumulative total). } \\
\text { 15. Reduction in the number of young families and young professionals in need of better } \\
\text { housing conditions in rural areas (cumulative). }\end{array}$ \\
\hline $\begin{array}{l}\text { Goal 12. Ensure } \\
\text { rational consumption } \\
\text { and production } \\
\text { models. }\end{array}$ & 13 & & \\
\hline $\begin{array}{l}\text { Goal 13. Take urgent } \\
\text { action to combat } \\
\text { climate change and } \\
\text { its consequences. }\end{array}$ & 4 & & \\
\hline $\begin{array}{l}\text { Goal } 14 \text { Conserve } \\
\text { and sustainably use } \\
\text { the oceans, seas and } \\
\text { marine resources. }\end{array}$ & 4 & & \\
\hline $\begin{array}{l}\text { Goal 15. Protect, } \\
\text { restore and promote } \\
\text { sustainable use of } \\
\text { land ecosystems, } \\
\text { manage forests, } \\
\text { combat } \\
\text { desertification, halt } \\
\text { and reverse land } \\
\text { degradation, and halt } \\
\text { the loss of biological } \\
\text { diversity. }\end{array}$ & 22 & 2 & $\begin{array}{l}\text { 3. Protection and conservation of agricultural land from wind erosion and desertification through } \\
\text { agro forestry and phytomelioration activities. } \\
\text { 5. Protection of land from water erosion, flooding through flood control measures, clearing of } \\
\text { reclamation channels, major repairs of reclamation facilities and technical equipment of } \\
\text { operational organizations. }\end{array}$ \\
\hline $\begin{array}{l}\text { Goal 16. Promote } \\
\text { peaceful and open } \\
\text { societies for } \\
\text { sustainable } \\
\text { development, ensure } \\
\text { access to justice for } \\
\text { all, and create } \\
\text { effective, accountable } \\
\text { and participatory } \\
\text { institutions at all } \\
\text { levels. }\end{array}$ & 19 & & \\
\hline $\begin{array}{l}\text { Goal 17. Strengthen } \\
\text { the means to achieve } \\
\text { sustainable } \\
\text { development and } \\
\text { enhance the global } \\
\text { partnership for } \\
\text { sustainable } \\
\text { development. }\end{array}$ & 19 & 2 & $\begin{array}{l}\text { 8. The number of results of research and development and experimental works of an innovative } \\
\text { nature in the reclamation complex. } \\
\text { 10. Preserving existing and creating new high- tech jobs for agricultural producers by increasing } \\
\text { the productivity of existing ones and involving new agricultural land in turnover. }\end{array}$ \\
\hline
\end{tabular}




\section{CONCLUSION}

Thus, the socio-economic development of the Russian Federation is impossible without taking into account regional features, in particular, the strengths and weaknesses of regional economic system, favorable and negative trends in regional development. This is due to the significant differentiation in economic and social resources support observed in different regions. At the regional level the main socio-economic development projects are implemented, the key social needs of the population are supplied. Regional economic development indicators are the main sustainable development criteria of the region in accordance with sustainable development goals. Immediacy of the problem is the absence of indicators for some sustainable development goals that can significantly characterize the current situation in the region to achieve the sustainable development goals.

\section{REFERENCES}

[1] Rio Declaration on environment and development URL:

http://www.un.org/ru/documents/decl_conv/declarations/ri odecl.shtml.

[2] S. A. Evteeva and R. A. Poletov, Our common future: Report of the International Commission on environment and development (ICOSR): TRANS, Edited and with afterword, M.: Progress, 1989. - 21 p.

[3] Dreyer O. K., Los V. A. Ecology and sustainable development. - Moscow: URAO publishing House, 1997.

[4] Lemetti Y. A. Strategy for sustainable development of agriculture of the region: theory and practice, Tver: publishing house of the Tver state agricultural Academy, 2011, 166 p.

[5] Report on human development in the Russian Federation for 2016. Short version / edited By S. N. Bobylev and L. M. Grigoriev. Analytical center under the Government of the Russian Federation, 2016. 44 p.

[6] Kohanenko D.V., Alyabyeva E.V., Ilina M.A., Application of time series for studying interregional migration on the example of the Altai territory, 2016, No 1. Pp. 146-158.

[7] Bogdanova M. M., Kolesnikova E. G., Tsoi R. A., Shchetinin E. N., State support of agriculture in the regions: a comparative analysis of the effectiveness of implementation, Financial business. 2017. No. 4 (189). Pp. 11-22.

[8] Region of Russia. Socio-economic indicators. 2019: P32 Stat. sat. / Rosstat. - Moscow, 2019. - 1204 p.

[9] Buhay A., Korenev S. A. Problems of sustainable development of rural territories, Bulletin of the Altai agrarian University, 2013, No. 1, pp. 142-145.

[10] Glubokova L. G., Semikolenova M. N., Glubokov I. O., Strategic analysis of the external environment of agricultural organizations in the Altai territory, Bulletin of the Kursk state agricultural Academy. 2018. No. 5. Pp. 157-163.

[11] Tretyakova L. A. Organizational and economic bases of sustainable development of rural territories, Orel: Orel publishing house of GAU, 2008, 360 sec.

[12] E. N. Feoktistova, G. A. Kopylova, M. N. Ozeryanskaya, M. V. Moskvina, N. I. Hofmann, D. R. Purtova, Russian business and sustainable development Goals. Collection of corporate practices, RSPP, Moscow, 2018-200 p.

[13] Merenkova I. N., Pertsev V. N. Ensuring sustainable development of rural territories of the municipal district, Voronezh: state NIIEOAPK Central Chernozem region of Russia, 2011, 166 p.

[14] Materials of the World Bank - [Electronic resource] access Mode: http://www.un.org/ru/youthink/mdg.shtml

[15] Merzlov A.V. Regional experience in the development of programs for sustainable development of rural territories, Moscow: Rosinformagrotech, 2012, 112 p.

[16] Rostov region-movement towards sustainable development goals. Inform.-anal.mate./ Rotostat, Rostov on Don, 2019, 202 p. 